\title{
Clostridium butyricum-containing Probiotic
}

National Cancer Institute

\section{Source}

National Cancer Institute. Clostridium butyricum-containing Probiotic. NCI Thesaurus.

Code C122837.

A probiotic containing the anaerobic, butyric acid-forming Gram-positive bacterium Clostridium butyricum (C. butyricum), with potential immunomodulatory activity. Upon oral administration of $\mathrm{C}$. butyricum-containing probiotic, $\mathrm{C}$. butyricum modulates the composition of the normal gastrointestinal (GI) microflora and help maintain adequate colonization of the Gl tract, thereby improving digestion and preventing Gl disturbances. This bacterium creates an environment unfavorable to pathogens by adhering to human epithelial cells, thereby forming a protective mucosal barrier. This prevents attachment of pathogens and reduces the risk of infection. Dietary supplementation with this bacterium may restore or enhance intestinal immunity. 